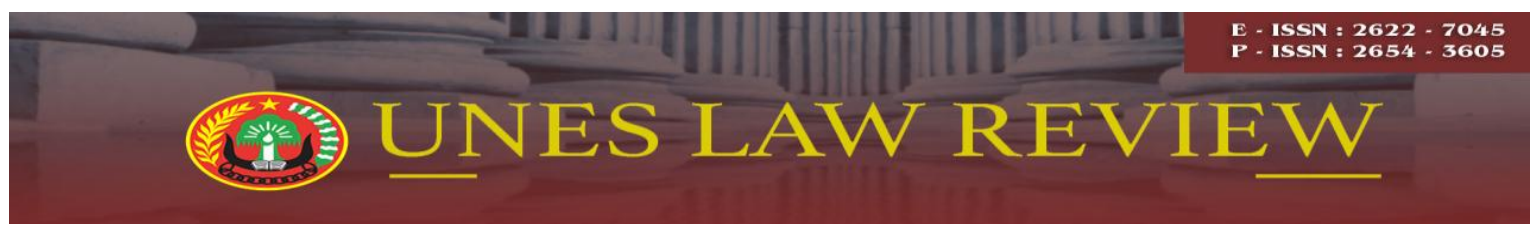

Email: uneslawreview@gmail.com

Online: http://review-unes.com/index.php/law

Volume 2, Issue 4, Juni 2020

\title{
KEBERADAAN FORUM KOORDINASI KEPEMIMPINAN (FORKOPIMDA) \\ PADA SISTEM PEMERINTAH DAERAH DI KABUPATEN TANAH DATAR
}

\author{
Bagus Tri Kuntjoro \\ Program Magister Ilmu Hukum, Universitas Ekasakti, Padang, Indonesia \\ Email: bagustri.kuntjoro@yahoo.com
}

\begin{abstract}
The Regional Leadership Coordination Forum, hereinafter referred to as Forkopimda, is a forum used to discuss the implementation of general government affairs. In accordance with article 26 of Law No. 23 of 2014 stated that the District Forkopimda was led by the Regent with members including the DPRD Chairperson, the Police Chief, the Prosecutor's Office and the territorial leadership of the TNI in the regions. The issues raised as the subject of this research study are: First, What is the existence of the Regional Leadership Coordination Forum (FORKOPIMDA) in the regional government system? Second, how is the existence of the Regional Leadership Coordination Forum (FORKOPIMDA) in order to maintain stability in the region in terms of ideology, politics, economy, social culture, and defense and security. This research is an analytical descriptive research with normative juridical approach supported by empirical juridical research. The data used are secondary and primary data collected through literature studies and interviews, analyzed qualitatively to get answers about the existence of the Regional Leadership Coordination Forum in the government system in Tanah Datar District which is the study of this study. Based on the results of research and discussion, it can be concluded that the Regional Leadership Coordination Forum (Forkopimda) Tanah District has the role and duty of fostering, maintaining peace and order of the community against the possibility of the threat of national stability and stability of Tanah Datar regency carried out through FORKOPIMDA meetings and activities field observations both periodically and incidentally by looking at events or problems that arise in the Tanah Datar District. While the existence of the Regional Leadership Coordination Forum (Forkopimda) of Tanah Datar District was very much felt and assisted the Tanah Datar Regency Government in creating security, order and legal certainty in community life and ensuring the implementation of development in Tanah Datar District which had the slogan "Adat Basandi Syarak, Syarak Basandi Kitabbullah "which in turn can improve the welfare of the people of Tanah Datar District.
\end{abstract}

Kata Kunci: Keberadaan Forum Koordinasi Kepemimpinan, Sistem, Pemerintahan Daerah 


\section{PENDAHULUAN}

Perkembangan reformasi di segala aspek bidang kehidupan dan pemerintahan serta demokratisasi yang semakin membaik membawa konsekuensi pada tuntutan pelaksanaan pemerintahan dan pembangunan yang semakin transparan dan akuntabel.

Masyarakat semakin mengerti, kritis, dinamis dan aspiratif terhadap penyelenggaraan pemerintahan, oleh karena itu lembaga pemerintahan semakin dituntut untuk lebih baik dan dekat dengan masyarakat. Penyelenggaraan pemerintahan yang menganut prinsip-prinsip good governance ini juga akan menuntut adanya koordinasi yang erat antara stakeholders.

Koordinasi yang baik ini akan mampu menjaga aspek transparansi dan akuntabilitas penyelenggaraan pemerintahan, lebih terjaminnya aliran arus aspirasi dan tersampaikannya kebijakan dan program pembangunan dari Pemerintah kepada masyarakat. Kebijakan pembangunan dari Pemerintah bagi masyarakat luas diharapkan masyarakat tidak hanya menerima bagaimana kebijakan itu ditetapkan, bagaimana kebijakan dilaksanakan, berperan serta dalam pelaksanaan dan dampak kegiatan kepada masyarakat luas.

Sistem pemerintahan Indonesia mengenal adanya jenis pembagian kewenangan baik antara kewenangan Pemerintah Pusat maupun kewenangan Pemerintah Daerah. Dalam pembentukan produk hukum baik pusat maupun daerah, undang-undang memberikan peranan dan fungsi terhadap elemen pemerintahan baik yang dipusat maupun daerah.

Kewenangan daerah membentuk peraturan daerah merupakan manifestasi dari otonomi daerah. Undang-Undang Dasar 1945 Pasal 18 mengakui adanya kewenangan daerah yang didasari pada asas otonomi daerah. Daerah otonom, selanjutnya disebut daerah, adalah kesatuan masyarakat hukum yang mempunyai batas-batas wilayah yang berwenang mengatur dan mengurus urusan pemerintahan dan kepentingan masyarakat setempat menurut prakarsa sendiri berdasarkan aspirasi masyarakat dalam sistem Negara Kesatuan Republik Indonesia.

Indonesia mendeklarasikan bentuk negara dalam Pasal 1 ayat (1) Undang-Undang Dasar Negara Republik Indonesia Tahun 1945 dalam kerangka Negara Kesatuan Republik Indonesia. Implikasi dari bentuk negara kesatuan dengan kondisi geografis negara 
berkepulauan, melahirkan upaya penyelenggaraan negara melalui asas desentralisasi dalam kerangka otonomi daerah, hal ini ditujukan guna meningkatkan efektifitas dan efisiensi pengelolaan negara.

Negara Kesatuan Republik Indonesia dibagi atas daerah-daerah provinsi dan daerah provinsi itu dibagi atas kabupaten dan kota, yang tiap-tiap provinsi, kabupaten, dan kota itu mempunyai pemerintahan daerah, yang diatur dengan undang-undang.

Pembagian tersebut merupakan perwujudan pelaksanaan fungsi dan prinsip otonomi daerah dengan pembagian daerah-daerah otonom, hal ini sebagaimana dimaksud dalam konstitusi Pasal 18 ayat (1) UUD NKRI 1945.

Reformasi telah memberikan kebijakan melalui otonomi daerah kepada daerah otonom, melalui pemberian kewenangan berupa sebagian besar kewenangan pemerintahan selain kewenangan yang ditentukan oleh undang-undang, untuk mengatur dan mengurus daerahnya masing-masing sesuai dengan aspirasi masyarakat setempat. Kewenangan mengatur dan mengurus merupakan kebijakan yang diberikan secara nyata kepada daerah untuk dilakukan oleh suatu pemerintahan daerah yang terdiri dari eksekutif dan legislatif.

Guna legalitas penyelenggaraan pemerintahan daerah dalam rangka mengatur dan mengurus daerahnya, Pemerintah Daerah dan Dewan Perwakilan Rakyat Daerah memerlukan suatu bentuk peraturan daerah. Hak untuk membentuk perda guna mendukung upaya penyelenggaraan pemerintahan daerah diberikan dan ditegaskan dalam Pasal 18 ayat (6) Undang-Undang Dasar Negara Republik Indonesia Tahun 1945, yang berbunyi:

"Pemerintahan daerah berhak menetapkan peraturan daerah dan peraturanperaturan lain untuk melaksanakan otonomi dan tugas pembantuan”, yang perancangannya dapat diajukan oleh Kepala Daerah maupun Dewan Perwakilan Rakyat Daerah, sebagaimana hal tersebut diatur dalam Pasal 140 ayat (1) UndangUndang Nomor 32 Tahun 2004 yang berbunyi: "Rancangan Perda dapat berasal dari DPRD, Gubernur, atau Bupati/Walikota".

Keterlibatan Rakyat dalam perumusan kebijakan dapat direalisasikan melalui wakil-wakilnya di Dewan Perwakilan Rakyat (DPR) untuk di tingkat Pusat dan Dewan Perwakilan Rakyat Daerah (DPRD). Oleh karena itulah Dewan Perwakilan Rakyat (DPR) mempunyai hak-hak yaitu hak interpelasi, hak menyatakan pendapat, hak bertanya, hak budget, dan hak angket. Dimana hak interpelasi adalah hak untuk meminta keterangan 
kepada pemerintah mengenai kebijakan pemerintah yang penting dan strategis serta berdampak luas pada kehidupan bermasyarakat berbangsa dan bernegara.

Sedangkan hak angket adalah hak DPR untuk melakukan penyelidikan terhadap pelaksanaan suatu Undang-undang atau kebijakan pemerintah yang berkaitan dengan hal penting strategis dan berdampak luas pada kehidupan bermasyarakat berbangsa dan bernegara yang diduga bertentangan dengan peraturan perundang-undangan. Sedangkan hak menyatakan pendapat adalah hak DPR untuk menyatakan pendapat atas tindak lanjut pelaksanaan interpelasi dan hak angket, kebijakan pemerintah atau mengenai kejadian luar biasa yang terjadi di tanah air dan dunia internasional.

Menurut ketentuan Pasal 10 UU No. 23 Tahun 2014, Urusan pemerintahan absolut meliputi:

1. politik luar negeri;

2. pertahanan;

3. keamanan;

4. yustisi;

5. moneter dan fiskal nasional; dan

6. agama.

Dalam menyelenggarakan urusan pemerintahan absolut, Pemerintah Pusat (a) melaksanakan sendiri; atau (b) melimpahkan wewenang kepada Instansi Vertikal yang ada di daerah atau Gubernur sebagai wakil Pemerintah Pusat berdasarkan asas Dekonsentrasi. Sedangkan urusan pemerintahan konkuren, ada yang menjadi kewenangan Pemerintah Pusat dan ada pula yang ditentukan sebagai kewenangan daerah.

Selanjutnya, dalam Pasal 14, ditentukan pula bahwa penyelenggaraan urusan pemerintahan bidang kehutanan, kelautan, serta energi dan sumber daya mineral dibagi antara Pemerintah Pusat dan Daerah Provinsi. Urusan pemerintahan bidang kehutanan sebagaimana dimaksud pada ayat (1) yang berkaitan dengan pengelolaan taman hutan raya Kabupaten/Kota menjadi kewenangan Daerah Kabupaten/Kota.

Urusan Pemerintahan bidang energi dan sumber daya mineral yang berkaitan dengan pengelolaan minyak dan gas bumi menjadi kewenangan Pemerintah Pusat. Urusan Pemerintahan bidang energi dan sumber daya mineral yang berkaitan dengan pemanfaatan langsung panas bumi dalam Daerah Kabupaten/Kota menjadi 
kewenangan Daerah kabupaten/kota. Daerah kabupaten/kota penghasil dan bukan penghasil mendapatkan bagi hasil dari penyelenggaraan Urusan Pemerintahan.

Penentuan Daerah kabupaten/kota penghasil untuk penghitungan bagi hasil kelautan adalah hasil kelautan yang berada dalam batas wilayah 4 (empat) mil diukur dari garis pantai ke arah laut lepas dan/atau ke arah perairan kepulauan. Dalam hal batas wilayah Kabupaten/Kota yang dimaksud kurang dari 4 (empat) mil laut, batas wilayahnya dibagi sama jarak atau diukur sesuai dengan prinsip garis tengah dari daerah yang berbatasan.

Pembagian urusan pemerintahan konkuren antara Pemerintah Pusat dan Daerah Provinsi serta Daerah Kabupaten/Kota dicantumkan pula secara eksplisit dalam lampiran yang merupakan bagian yang tidak terpisahkan dari UU No. 23 Tahun 2014 Tentang Pemerintahan Daerah. Sedangkan urusan-urusan pemerintahan konkuren lain yang tidak tercantum dalam lampiran undang-undang dianggap sebagai menjadi kewenangan tiap tingkatan pemerintahan atau susunan pemerintahan masing-masing, yang penentuannya dilakukan dengan menggunakan prinsip dan kriteria pembagian urusan pemerintahan konkuren seperti yang dimaksud di atas.

Urusan pemerintahan konkuren tersebut ditetapkan dengan peraturan presiden. Perubahan terhadap pembagian urusan pemerintahan konkuren antara Pemerintah Pusat dan Daerah Provinsi dan Daerah Kabupaten/Kota yang tidak berakibat pengalihan urusan pemerintahan konkuren pada tingkatan pemerintahan atau susunan pemerintahan yang lain juga ditetapkan dengan peraturan pemerintah.

Perubahan-perubahan yang dipandang penting dapat dilakukan sepanjang tidak bertentangan dengan prinsip dan kriteria pembagian urusan pemerintahan konkuren sebagaimana dimaksud di atas. Pasal 1, angka 18 UU No. 23 Tahun 2014 tentang Pemerintahan Daerah, Forum Koordinasi Pimpinan di Daerah yang selanjutnya disebut Forkopimda adalah forum yang digunakan untuk membahas penyelenggaraan urusan pemerintahan umum

Berdasarkan latar belakang pemikiran di atas, maka permasalahan yang dibahas dalam tulisan ilmiah ini adalah sebagai berikut:

1. Bagaimana eksistensi Forum Koordinasi Pimpinan di Daerah (FORKOPIMDA) dalam sistem pemerintahan Kabupaten Tanah Datar? 
2. Bagaimana eksistensi Forum Koordinasi Pimpinan di Daerah (FORKOPIMDA) dalam rangka menjaga stabilitas di wilayah baik dari sisi ideologi, politik, ekonomi, sosial budaya, serta pertahanan dan keamanan?

\section{METODE PENELITIAN}

Penelitian ini adalah suatu penelitian yang bersifat deskriptif analitis, yaitu untuk menggambarkan sekaligus menganalisis peraturan perundang-undangan dan teori-teori hukum yang berkaitan dengan koordinasi maupun sistem pemerintahan sebagai upaya untuk mengetahui tentang eksistensi Forkopimda dalam sistem hukum pemerintahan daerah di Kabupaten Tanah Datar.

Metode Pendekatan yang digunakan dalam penelitian ini yaitu pendekatan yuridis normatif. Penelitian Yuridis Normatif ialah penelitian hukum yang menggunakan sumber data sekunder. Sebagai penelitian hukum (yuridis) dengan objek kaidah-kaidah hukum pidana, pendekatan yang digunakan adalah pendekatan yuridis, yaitu pendekatan yuridis formal dan yuridis empiris. Titik berat pendekatan yuridis formal adalah pada materi muatan kaidah hukum pidana pengedaran sediaan pangan yang diteliti.

\section{HASIL PENELITIAN DAN PEMBAHASAN}

\section{Eksistensi FORKOPIMDA Dalam Sistem Pemerintahan di Kabupaten Tanah Datar}

Berdasarkan wawancara yang penulis lakukan dengan Bupati Tanah Datar tentang Eksistensi FORKOPIMDA Dalam Sistem Pemerintahan di Kabupaten Tanah Datar menyampaikan bahwa dengan adanya FORKOPIMDA dapat membantu kelancaran dan tugas-tugas pemerintahan daerah dimana Kabupaten Tanah Datar memiliki visi“Terwujudnya Masyarakat Kabupaten Tanah Datar Sejahtera dan Berkeadilan dilandasi Filosofi Adat Basandi Syarak, Syarak Basandi Kitabullah“.

Kegiatan-kegiatan FORKOPIMDA Kabupaten Tanah Datar mencakup hampir semua kegiatan yang memerlukan adanya koordinasi dan komunikasi antar pimpinan di daerah Kabupaten Tanah Datar, diantaranya :

1. Menjaga Stabilitas Nasional dan Stabilitas Daerah Kabupaten Tanah Datar.

FORKOPIMDA juga bertugas membina dan memelihara ketentraman dan ketertiban masyarakat terhadap kemungkinan timbulnya ancaman stabilitas nasional dan stabilitas daerah Kabupaten Tanah Datar. 
Stabilitas nasional adalah kestabilan atau situasi yang kondusif baik di bidang sosial budaya, politik, pemerintahan, keamanan, perekonomian, perdagangan, dan bidang-bidang lainnya, sehingga pemerintahan bisa berjalan dengan baik, rakyat bisa melakukan aktivitasnya dengan baik, dan program-program serta kebijakan pemerintah bisa dilaksanakan secara optimal dimana stabilitas nasional merupakan masalah penting dalam membangun keberlanjutan suatu bangsa. Ancaman terhadap keamanan dan ketahanan nasional itu bersifat laten dan bisa muncul secara mendadak, oleh karena ikhtiar membangun stabilitas dan ketahanan nasional semakna dengan upaya membantu kesadaran nasionalisme sehingga terbentuk sebuah kesadaran kolektif dari seluruh elemen bangsa dan Negara Indonesia untuk mempertahankan keutuhan bangsa dan Negara Indonesia.

Dengan demikian untuk menjaga stabilitas nasional maupun stabilitas daerah perlu adanya kesadaran setiap warga negara dalam bela negara. Dengan adanya FORKOPIMDA, maka tugas utama dalam menjaga stabilitas nasional maupun stabilitas daerah dapat dikoordinasikan dengan instansi lainnya khususnya intansi vertikal yang ada di daerah.

2. Membina Ketentraman dan Ketertiban Masyarakat

Hukum (law) pada umumnya bertujuan untuk mengadakan tata tertib atau ketertiban (order) guna keselamatan masyarakat, yang penuh dengan bentrokan antara berbagai kepentingan yang tersebar di tengah-tengah masyarakat. Aristoteles berpendapat tujuan hukum (law) adalah untuk mewujudkan keadilan. Ia mengenal dua macam keadilan, yaitu keadilan dstributif dan keadilan komutatif. Keadilan distributif ialah keadilan yang memberikan kepada setiap orang seimbang dengan jasa atau kualitasnya. Berarti, kepada setiap orang harus diberikan yang memenuhi kualitasnya. Keadilan komutatif ialah keadilan yang memberikan kepada setiap orang sama banyaknya dengan tidak mengingat kualitas perseorangan. Berarti, sedapat mungkin harus terdapat persamaan (keseimbangan) antara barang-barang yang dipertukarkan.

Berhubungan dengan penegakan hukum, maka dalam hal membina ketentraman dan ketertiban masyarakat ini dikoordinir oleh Kapolres Tanah Datar kecuali 3 Kecamatan yaitu Kecamatan Batipuh Selatan, Kecamatan Batipuh dan Kecamatan X Koto sedangkan ketiga kecamatan yang disebutkan diatas dikoordinasikan oleh Kapolres Padang Panjang.

Pembinaan dan pemeliharaan ketentraman dan ketertiban masyarakat hanya bisa dicapai jika tegaknya hukum di tengah masyarakat. Dalam penegakkan hukum ada tiga unsur yang selalu harus diperhatikan, yaitu :

a. kepastian hukum

b. kemanfaatan,

c. keadilan.

Hukum harus dilaksanakan dan ditegakkan, dimana setiap orang mengharapkan dapat ditetapkannya hukum dalam hal terjadi peristiwa yang konkrit. Masyarakat mengharapkan adanya kepastian hukum, karena dengan adanya kepastian hukum masyarakat akan lebih tertib dan masyarakat lebih tentram. Hukum bertugas menciptakan kepastian hukum karena bertujuan ketertiban masyarakat. Sebaliknya masyarakat mengharapkan manfaat dalam pelaksanaan atau penegakan hukum. Hukum 
adalah untuk manusia, maka pelaksanaan hukum atau penegakan hukum harus memberi manfaat atau kegunaan bagi

Salah satu penyebab terjadinya kejahatan adalah keadaan perekonomian masyarakat yang cenderung semakin sulit, sangat memprihatinkan dan menyulitkan masyarakat akibat kurangnya lapangan kerja, serta rendahnya tingkat penghasilan masyarakat merupakan beban yang dialami sebagian besar masyarakat saat ini. Berbagai hal tersebut menyebabkan mereka berusaha untuk menutupi kekurangan uang untuk memenuhi kebutuhan hidup, termasuk melakukan perbuatan yang bertentangan dengan aturan hukum yaitu dengan cara melakukan suatu tindak pidana.

Ketentraman dan ketertiban masyarakat tidak bisa hanya dilaksanakan oleh pihak Kepolisian saja, karena menyangkut kepentingan semua unsur dalam masyarakat. Sehinga peran Forkopimda untuk memelihara ketentraman dan ketertiban masyarakat sangat memerlukan.

3. Mengamankan Pelaksanaan Kebijakan Nasional dan Kebijakan Daerah

Dalam rangka mengamankan kebijakan nasional biasanya semua instansi dilibatkan dan evaluasi dilakukan setiap adanya pertemuan semua anggota FORKOPIMDA yang dipimpin oleh Bupati Kabupaten Tanah Datar. Sedangkan untuk kebijakan daerah bisa saja didahului oleh nota kesepakatan instansi yang terlibat secara langsung. Jadi Forum Komunikasi ini hanya bersifat mengamankan pelaksanaan kesepakatan yang dibuat. Sebagai Contoh Kesepatan antara Bupati dengan Dewan Perwakilan Rakyat. Kebijakan Umum Anggaran Pendapatan dan Belanja Daerah Kabupaten Tanah Datar .

4. Mengantisipasi Masalah Aktual

Mengantisipasi adalah membuat perhitungan (ramalan, dugaan) atas hal-hal yang belum maupun akan terjadi, atau memperhitungkan sebelum terjadi. Sebagai contoh saat ini terjadi wabah Corona tetapi di Kabupaten Tanah Datar belum ada yang terkena wabah, maka Pemerintah berusaha melakukan antisipasi agar wabah tersebut tidak terjadi atau jika terjadi mengantisipasi danpak yang ditimbulkan agar bisa ditekan seminimal mungkin.

Salah satu antisipasi masalah aktual akhir-akhir ini adalah mewabahnya Novel Corona Virus atau popular disebut dengan nama Covid 19, untuk itu Pemerintah Kabupaten Tanah Datar menindaklanjuti dengan menggelar rapat koordinasi lintas sektor untuk mengantisipasi penyebaran virus yang sudah menjadi pandemi ini. Dari hasil rakor diperoleh beberapa kesepakatan strategis di antaranya membentuk gugus tugas sesuai yang diamanatkan Keppres Nomor 7/2020 tentang pembentukan gugus tugas percepatan penanganan corona virus desease (Covid-19).

Berdasarkan SE Mendikbud nomor 3/2020 tentang pencegahan Covid-19 pada satuan pendidikan, pada awalnya tingkat resiko penyebaran covid-19 di Sumatera Barat saat ini berada dalam kategori rendah, dengan kriteria tidak ada anggota masyarakat di wilayah Kabupaten/Kota yang terjangkit virus Covid-19 sehingga belum perlu meliburkan peserta didik dan ini juga sudah disepakati pada Rakor di tingkat provinsi namun setelah diketahui adanya masyarakat (ASN Kabupaten Tanah Datar) yang sudah terjangkit Covid-2019 di Sumatera Barat (awalnya di Bukittinggi) yang diumumkan pada tanggal 27 Maret 2020 maka Bupati Tanah Datar sebagai Kepala Daerah sesuai 
dengan kewenangannya menetapkan kebijakan untuk meliburkan kelas peserta didik tersebut atau satuan pendidikan selama 14 hari. Sementara untuk ASN Kabupaten Tanah Datar masih tetap melaksanakan tugas seperti biasa dan program-program maupun kegiatan yang sudah diagendakan diupayakan diundur sampai setelah bulan Agustus 2020 kecuali kegiatan yang bersifat strategis ditunda 14 hari ke depan. Kebijakan lain yang diambil oleh Bupati Tanah Datar melalui Kepala Dinas Pariwisata menutup obyek wisata salah satunya yaitu Istano Pagaruyung.

Pada kondisi begini, maka peran FORKOPIMDA Kabupaten Tanah Datar betul-betul dapat dirasakan. Semua instansi melakukan koordinasi dengan baik dimana kegiatan rapat rutin diadakan sekali dalam sebulan, sejak merebaknya kasus Covid-19 ini rapat rutin diadakan tiap minggu dan bahkan bisa diadakan sewaktu-waktu.

5. Mengamankan Pelaksanaan Kebijakan Nasional dan Kebijakan di Daerah

Forkopimda Kabupaten Tanah Datar mengamankan semua kebijakan Nasional maupun kebijakan Daerah yang telah ditetapkan oleh pejabat berwenang di tingkat Pusat maupun tingkat Provinsi. Sebagai contoh kebijakan tentang mengatasi Covid 19 diantaranya yaitu : meliburkan segala bentuk kegiatan pendidikan mulai dari SD sampai dengan SMA, sedangkan khusus untuk mahasiswa yang belajar di kampus diganti dengan sistem daring; menghentikan dan melarang segala kegiatan publik atau kegiatan yang melibatkan banyak orang seperi pernikahan, sholat di mesjid, gereja, menjaga jarak antara sesama dengan kisaran 1 meter, untuk daerah yang gawat Covid19 di anjurkan memakai masker, menggunakan Hand Sanitizer, mencuci tangan setiap selesai kegiatan, menjaga kebersihan diri dan lingkungan, melarang bepergian keluar negeri;

Masing-masing anggota FORKOPIMDA mengamankan kebijakan tersebut dengan cara mensosialisasikan di organisasi terkati dan secara keseluruhan beberapa Forkopimda tergabung dalam Satuan Gugus Tugas yang dipimpin oleh Wakil Bupati Tanah Datar. Gugus tugas itu sendiri disamping sebagian yang ada di Forkopimda ditambah dengan Kepala Dinas Kesehatan Kabupaten Tanah Datar.

6. Hubungan kerja FORKOPIMDA dengan Pemerintah Daerah

Hubungan kerja yang harmonis akan memengaruhi tensi di daerah, kalau ada masalah dan ada yang tidak rukun, satu saja akan menjadi masalah besar dalam menangani problem di daerah. Penanganan preventif dalam persoalan hukum yang berpotensi memunculkan konflik dan menghambat pembangunan.

Penyelenggaraan pemerintahan di daerah sangatlah kompleks, maka harus melibatkan berbagai unsur yang dipimpin oleh anggota FORKOPIMDA. Hubungan yang harmonis tersebut dapat dilihat dari berbagai kerjasama yang dibuat antar intansi vertikal atas suatu hal sehingga penanganan dapat lebih obyektif, efektif dan efisien.

\section{Eksistensi FORKOPIMDA dalam rangka menjaga stabilitas di wilayah baik dari sisi ideologi, politik, ekonomi, sosial budaya serta pertahanan dan keamanan}

Berdasarkan wawancara penulis dengan Kepala Badan Kesbangpol Kabupaten Tanah Datar banyak hal yang telah diperankan oleh FORKOPIMDA dalam rangka 
menjaga stabilitas di wilayah Kabupaten Tanah Datar baik dari sisi ideologi, politik, ekonomi, sosial budaya serta pertahanan dan keamanan. Stabilitas di Kabupaten Tanah Datar adalah kestabilan atau situasi yang kondisif baik di bidang ideologi, politik, ekonomi, sosial budaya, pertahanan dan keamanan, sehingga pemerintahan bisa berjalan dengan baik, rakyat bisa melakukan aktivitasnya dengan baik, dan program-program serta kebijakan pemerintah di daerah kabupaten tanah datar bisa dilaksanakan secara optimal

Stabilitas ideologi dan politik Kabupaten Tanah Datar sangat kondusif , dimana hal ini terbukti dalam pelaksanaan Pemilu Presiden maupun Pemilu Legislatif berjalan dengan aman dan tidak ada kejadian yang menonjol hal ini merupakan tolak ukur keberhasilan FORKOPIMDA dalam menjaga stabilitas di wilayah. Sedangkan stabilitas daerah Kabupaten Tanah Datar dari sisi ekonomi disamping cenderung berpegang pada ekonomi syariah maka ekonomi yang dikembangkan adalah ekonomi kreatif. Ekonomi kreatif diartikan sebagai sebuah konsep ekonomi yang mendasarkan pada kreatifitas sebagai aset utama dalam pembangunan ekonomi yang berkelanjutan. Kreatifitas dianggap sebagai aset penting atau modal dasar dalam pembangunan ekonomi yang perlu dikembangkan dan ditingkatkan. Ekonomi kreatif lebih mengedepankan pengembangan kempuan.

Selain ini dibidang sosial budaya bahwa masyarakat Tanah Datar sejak dahulu dikenal memiliki nilai-nilai seni-budaya dan tradisi yang unik yang bersumber ajaran agama yang dianut, yakni Islam. Di luar itu, mereka memiliki sejumlah nilai-budaya lokal yang khas, yang membuat mereka berhasil mengembangkan industri pariwisata dan ekonomi kreatif berbasis budaya. Mereka memiliki etos kreatif tertentu yang menyebabkannya bisa maju, berkembang, dan unggul di tengah maraknya persaingan global. Dimana setiap individu untuk dapat lebih berkarya sehingga kesejahteraan masyarakat tercipta dengan sendirinya.

Stabilitas dibidang pertahanan dan keamanan di wilyah Kabupaten Tanah Datar dapat dikatakan cukup mantap hal ini dapat kita lihat bahwa tidak ada gaanguan pertahanan yang terjadi, sedangkan gangguan keamanan yang terjadi merupakan tindak pidana konvensional yang dapat diselesaikan oleh pihak yang berwenang dalam hal ini Polres Tanah Datar maupun Polres Padang Panjang. Dengan indiktor tersebut diatas dapatlah kita tarik suatu kesimpulan bahwa eksistensi FORKOPIMDA sangatlah berdampak terhadap 
terjadinya ataupun rendahnya angka kriminalistas maupun tindak pidana di wilayah Kabupaten Tanah Datar.

\section{PENUTUP}

Berdasarkan pembahasan sebagaimana yang telah dipaparkan di atas, maka penulis dapat menarik kesimpulan sebagai berikut:

Eksistensi Forum Koordinasi Pimpinan di Daerah (FORKOPIMDA) dalam sistem pemerintahan Kabupaten Tanah Datar adalah sangat dirasakan dan membantu Pemerintah Kabupaten Tanah Datar dalam menciptakan kondisi keamanan, ketertiban maupun kepastian hukum dalam kehidupan masyarakat serta menjamin pelaksanaan pembanguan di Kabupaten Tanah Datar yang mempunyai semboyan " Adat Basandi Syarak, Syarak Basandi Kitabbullah" yang pada akhirnya dapat meningkatkan kesejahteraan masyarakat Kabupaten Tanah Datar.

Eksistensi Forum Koordinasi Pimpinan di Daerah (FORKOPIMDA) dalam rangka menjaga stabilitas di wilayah baik dari sisi ideologi, politik, ekonomi, sosial budaya, serta pertahanan dan keamanan adalah sangat diperlukan dimana FORKOPIMDA mempunyai peran dan bertugas membina, memelihara ketentraman serta ketertiban masyarakat terhadap kemungkinan timbulnya ancaman stabilitas nasional dan stabilitas daerah di Kabupaten Tanah Datar baik dari sisi ideolog, politik, ekonomi, soaial budaya serta pertahanan dan keamanan yang dilaksanakan melalui rapat-rapat FORKOPIMDA maupun kegiatan peninjauan dilapangan baik secara periodik maupun secara insidentil dengan mencermati kejadian ataupun permasalahan yang timbul di wilayah Kabupaten Tanah Datar.

\section{DAFTAR PUSTAKA}

Abdul Azis dan Mariyah Ulfah, Kapita selekta ekonomi Islam kontemporer, PT. Alfabeta, Bandung, 2010.

Achmad Ali, Menguak Tabir Hukum (Suatu Kajian Filosofis dan Sosiologis), Penerbit Toko Gunung Agung, Jakarta, 2002.

Agung Djojosoejarto, dan Marselina Djayasinga, Membangun Kapasitas Fungsi Penganggaran DPRD. Konrad Adenauer Sitiftung (KAS), Bina Aksara, Jakarta, 2004. 
Franklin and Marshal College, Lancaster, Lebih lanjut temukan dalam Roscoe Pound "The Task of Law", Pennsylvania, 1944.

H.A.S Moenir. Manajemen Pelayanan Umum. PT. Bumi Aksara, Jakarta, 1995.

Hanif Nurcholis, Teori danPraktek Pemerintahan dan Otonomi Daerah, Grasindo, Jakarta, 2005.

Heriyanto, Memahami Tugas dan Wewenang DPR, DPD, dan DPRD, Bina Aksara, Jakarta, 2002.

Johny Ibrahim, Teori \& Metodologi Penelitian Hukum Normatif, Bayumedia Publishing, Malang Jawa Timur, 2006.

Lili Rasjidi dan I.B Wyasa Putra, Hukum sebagai Suatu Sistem, Remaja Rosdakarya, Bandung, 1993.

Mochtar Kusumaatmadja, Konsep-Konsep Pembangunan Hukum dalam Pembangunan, Alumni-Bandung, 2002.

Peter Mahmud Marzuki, Pengantar Ilmu Hukum, Kencana, Jakarta, 2008.

Riduan Syahrani, Rangkuman Intisari Ilmu Hukum, Penerbit Citra Aditya Bakti,Bandung, 1999.

Sadjijono, Memahami Hukum Kepolisian, LakBang Pressindo, Yogyakarta, 2010.

Salim HS dan Erlies Septiana Nurbani, Penerapan Teori Hukum pada Penelitian Tesis dan Desertasi, PT. RajaGrafindo Persada, Jakarta, 2013.

Soejono Soekanto, Sosiologi; Suatu Pengantar, Rajawali Press, Bandung, 1983 , Pengantar Penelitian Hukum, Universitas Indonesia, Jakarta, 2014.

Soejono Soekarno dan Srie Mamuji, Penelitian Hukum Normatif, Suatu Tinjauan Singkat, Rajawali Perss, Jakarta, 1985.

Soetanto Soepiadhy, Kemanfaatan Hukum, Universitas Tarumanegara, Surabaya pagi.com, 2013.

Sutikno Martokusumo, Mengenal Hukum (Suatu Pengantar), Liberty, Yogyakarta, 1988.

Theo Hujbuers, Filsafat Hukum Dalam Lintasan Sejarah, Kanisius, Jakarta,1982.

Wasistiono dan Yonatan, Meningkatkan Kinerja Dewan Perwakilan Rakyat Daerah (DPRD), Fokusmedia, Jakarta, 2005.

Valerine J.L. Kriekhoff, Mediasi (Tinjauan dari Segi Antropologi Hukum), dalam Antropologi Hukum Sebuah Bunga Rampai oleh T.O. Ihromi, Yayasan Obor, Jakarta, 2001 